\title{
RADIOCARBON DATING OF SHELLS AND FORAMINIFERA FROM THE SKAGEN CORE, DENMARK: EVIDENCE OF REWORKING
}

\author{
SUSANNE HEIER-NIELSEN,${ }^{1,2}$ KELD CONRADSEN, ${ }^{1}$ JAN HEINEMEIER, ${ }^{2}$ K. L. KNUDSEN, ${ }^{1}$ \\ H. L. NIELSEN, ${ }^{2}$ NIELS RUD ${ }^{2}$ and Á. E. SVEINBJÖRNSDÓTTIR ${ }^{3}$
}

\begin{abstract}
We report on 69 radiocarbon dates of mollusk shells and benthic foraminifera from the upper $132 \mathrm{~m}$ of the marine shelf sediments of the Skagen Core ( $220 \mathrm{~m}$ total length). The dated sequence covers the Late Glacial and the Holocene (from $15 \mathrm{ka} \mathrm{BP}$ to Recent). Sedimentation rates range from 1 to $70 \mathrm{~m} \mathrm{ka}^{-1}$. The macrofossil shell dates follow a smooth curve constituting an age model for dating the sediments. The foraminiferal dates fall into two groups: those that agree exactly with the mollusk shells and those that deviate substantially, always being older than the shells by as much as $5 \mathrm{ka}$. One mixed foraminiferal sample consisted of members from both groups, and as a result, the age deviation of the sample turned out to be some weighted average. The data indicate that the age deviations are due to admixtures of reworked older foraminifera.
\end{abstract}

\section{INTRODUCTION}

Since the introduction of accelerator mass spectrometry (AMS), it has been possible to radiocarbondate marine sediment cores by using samples of foraminifera, either single species or mixed faunas (Broecker et al. 1984). Compared to conventional ${ }^{14} \mathrm{C}$ dating of bulk sediment carbonate, one would expect AMS dating of foraminifera to be more reliable and give improved resolution limited only by the degree of bioturbation. However, data show problems other than bioturbation in using foraminifera as a dating material. Reports appear in the literature of age inversions, high core-top ages (Jones et al. 1989) and deviating ${ }^{14} \mathrm{C}$ ages for sample pairs of different (planktonic) foraminiferal species (Broecker et al. 1988, 1989; Bard et al. 1989; Jones et al. 1989). It seems that the reliability of foraminifera as a dating tool in establishing sediment chronologies has not been tested as thoroughly as "traditional" dating samples, such as mollusk shells and wood-often due to the absence of such reference material for cross-checking. Thus, it is often difficult to distinguish between possible causes of observed age anomalies as, e.g., carbonate dissolution effects or reworking in high-depositionrate, deep-sea cores (Broecker et al. 1989).

In a series of dates on coastal or shallow marine cores from Danish waters (Core 95, Limfjorden; Core PC10-1, Kattegat), we observed large deviations among ${ }^{14} \mathrm{C}$ age profiles determined on foraminifera as compared to mollusk shells (Nielsen 1992; Seidenkrantz and Knudsen 1993). However, two fossil types from Cores B and E, Bjørnsholm Bay, Limfjorden, agreed well (Kristensen, HeierNielsen and Hylleberg 1995).

To clarify the extent to which foraminifera can be trusted as a dating medium, we chose a core from North Denmark with a uniquely high sedimentation rate (on the order of $10 \mathrm{~m} \mathrm{ka}^{-1}$ ) and many macrofossil shells. We argue that the macrofossil shells yield the true age of the sediment and can be used as an absolute reference for dating foraminifera. The high sedimentation rate eliminates bioturbation effects, and the macrofossils are less likely to be geologically disturbed by reworking. We report $69{ }^{14} \mathrm{C}$ dates, for which we observed many substantial age differences between foraminifera and macrofossil shells. We address the question whether these discrepancies are of experimental or geological origin.

\footnotetext{
${ }^{1}$ Department of Earth Sciences, University of Aarhus, DK-8000 Aarhus C, Denmark

${ }^{2}$ AMS ${ }^{14} \mathrm{C}$ Dating Laboratory, Institute of Physics and Astronomy, University of Aarhus, DK-8000 Aarhus C, Denmark

${ }^{3}$ Science Institute, University of Iceland, Dunhagi 3, IS-107 Reykjavík, Iceland
} 


\section{METHODS}

The Skagen Core location is onshore (1 $\mathrm{m}$ above sea level) at the Skaw Spit (Skagen Odde), near the northernmost point of the peninsula of Jutland (Fig. 1). The 35-km-long coastal spit—one of the largest in the world of its kind-has gradually grown north during the last $8 \mathrm{ka}$. The sediments forming the spit are mainly derived from the southern and eastern North Sea and transported with the Jutland Current to the accumulation area that can be regarded as a giant natural sediment trap.

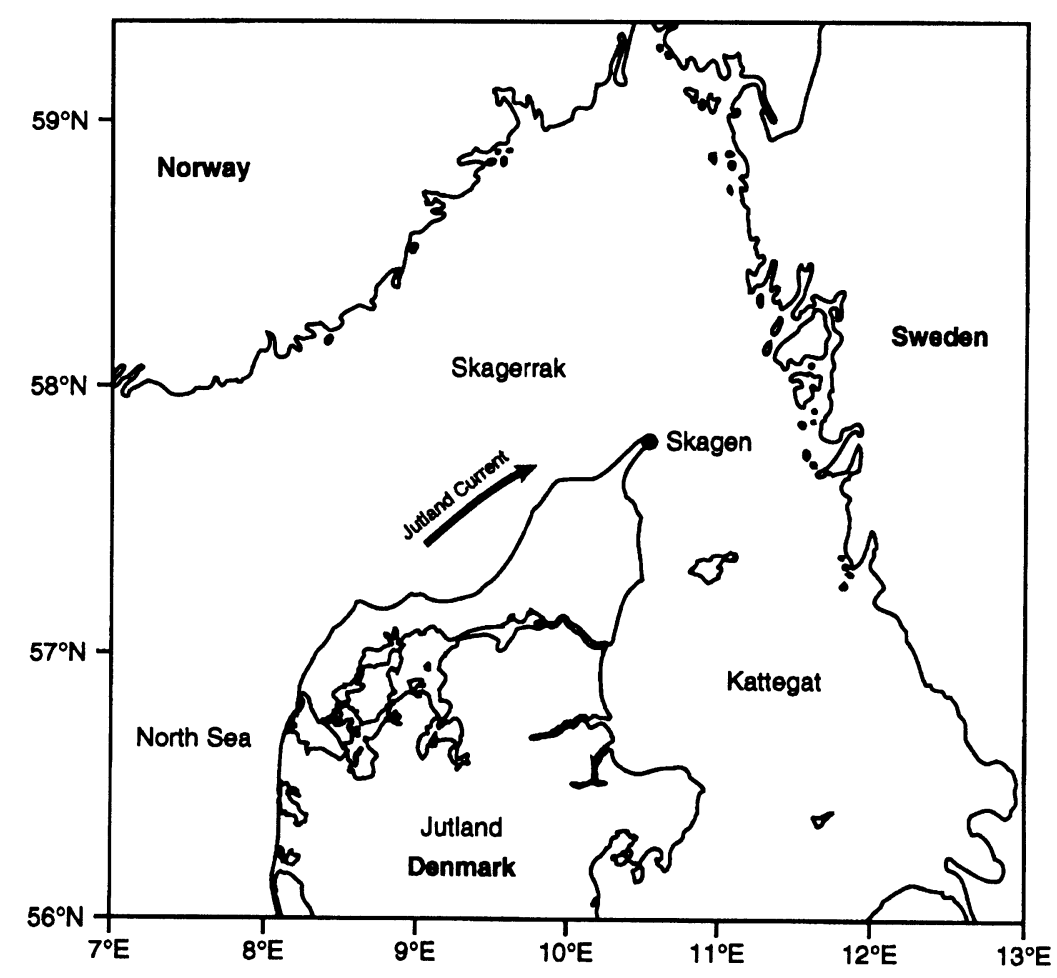

Fig. 1. Locality map

The core penetrates $200 \mathrm{~m}$ of Quaternary sediments, the upper $132 \mathrm{~m}$ of which are continuous marine deposits of Late Glacial and Holocene age (from $15 \mathrm{ka}$ BP to Recent) (Knudsen 1994). Lithologically, the sequence is divided into three broad zones: $132-81 \mathrm{~m}$ is clayey; $81-c a .30 \mathrm{~m}$ is siltysandy; the top $30 \mathrm{~m}$ consists of coarse sand.

The core was taken with rotating drilling equipment in subcores $1.50 \mathrm{~m}$ long and $10 \mathrm{~cm}$ in diameter. The main core (Skagen 3) was supplemented with a parallel core (Skagen 4), which was taken with different equipment to produce an intact record also for the top $30 \mathrm{~m}$ of coarse sand. Foraminifera were extracted from bulk sediment subsamples covering $2-$ or $5-\mathrm{cm}$ intervals. To avoid downcore contamination with younger material, we removed the outer $1 \mathrm{~cm}$ of the sediment ("core bark") prior to processing of the samples. Conradsen and Heier-Nielsen (1995) gave a detailed description and paleoenvironmental interpretation of the core, based on foraminiferal analysis. From local coastline displacement data and global sea-level history (Fairbanks 1989), we estimated that the water depth at the time of deposition of a given sediment level is of the same order as its depth in the core. 
We processed the sediment samples using standard techniques (Feyling-Hanssen et al. 1971), i.e., wet sieving followed by density separation in $\mathrm{CCl}_{4}\left(\rho=1.59 \mathrm{~g} \mathrm{~cm}^{-3}\right)$ of the fraction for $0.1-1.0 \mathrm{~mm}$. We saw no evidence of contamination effects from the carbon content in $\mathrm{CCl}_{4}$. Benthic foraminifera were subsequently hand-picked from the light fraction. Samples of macrofossil shells or shell fragments for ${ }^{14} \mathrm{C}$ dating were mostly taken from the $>1 \mathrm{~mm}$ fraction after wet sieving. The fragments often came from whole shells crushed as a result of sediment compaction.

For the macrofossil shell samples, we followed the standard mollusk-rinsing procedure (Olsson and Blake 1961; Andersen 1968). To eliminate any possible surface contamination, the outer $25 \%$ of the sample was removed by etching in $1 \mathrm{M} \mathrm{HCl}$. Any organic carbon was removed by treatment with a $\mathrm{KMnO}_{4}$ solution for $16-20 \mathrm{~h}$ at $80^{\circ} \mathrm{C}$. The $\mathrm{CO}_{2}$ was liberated with $\sim 100 \%$ phosphoric acid in an evacuated vial at $25^{\circ} \mathrm{C}$. Part of the $\mathrm{CO}_{2}$ was used for $\delta^{13} \mathrm{C}$ measurements. The rest was converted to graphite for AMS ${ }^{14} \mathrm{C}$ measurements by reduction with $\mathrm{H}_{2}$ by using cobalt as a catalyst. We used small reaction volume and a high initial pressure of the reacting gases (Vogel et al. 1984).

The foraminifera were pretreated similarly, but surface etching and organic carbon removal were omitted. If present, surface contamination would be difficult to eliminate because foraminiferal shells are so thin that they are virtually "all surface". We have good reasons to believe that the surfaces were not contaminated, at least in the present core. The exact agreement observed between several foraminiferal samples-monospecific as well as mixed-and the corresponding shells support this. Further, we compared the ${ }^{14} \mathrm{C}$ ages of etched and untreated foraminifera and found no difference. It is interesting to note that analogous experiments with shells gave the same result. In most cases the etching step could probably be omitted for macrofossil shells as well.

All ${ }^{14} \mathrm{C}$ measurements were performed on the Aarhus EN tandem accelerator (Andersen et al. 1989) and the $\delta^{13} \mathrm{C}$ measurements were performed on the mass spectrometer at the Science Institute, Reykjavík, Iceland. The quoted uncertainties are based on ion-counting statistics. A series of ${ }^{14} \mathrm{C} /{ }^{13} \mathrm{C}$ measurements with statistical uncertainties of $0.25-0.75 \%$ submitted to the Third International Radiocarbon Intercalibration (TIRI) indicate that this is the dominant source of uncertainty.

Dates are reported as conventional ${ }^{14} \mathrm{C}$ ages in years BP (before 1950), based on the measured ${ }^{14} \mathrm{C} /{ }^{13} \mathrm{C}$ ratio corrected for the natural isotopic fractionation by normalizing the result to the standard $\delta^{13} \mathrm{C}$ value of $-25 \%$ PDB (Stuiver and Polach 1977; Andersen et al. 1989). ${ }^{14} \mathrm{C}$ dates of marine samples were corrected for the apparent age of modern marine water (reservoir effect). A standard reservoir age of $400 \mathrm{yr}$ (Krog and Tauber 1974; Nielsen et al. 1994) is subtracted from the conventional ${ }^{14} \mathrm{C}$ age to obtain the reservoir-corrected ${ }^{14} \mathrm{C}$ age. It is used throughout the text and figures to facilitate comparison with terrestrial ${ }^{14} \mathrm{C}$ dates.

\section{RESULTS AND DISCUSSION}

Table 1 lists the ${ }^{14} \mathrm{C}$ dating results for shells and mixed/monospecific foraminifera samples from the Late Glacial and Holocene part of the Skagen Core (132 m and upwards) together with the measured $\delta^{13} \mathrm{C}$ values. The same data are plotted in Figures 2 and 3 . Table 1 also lists age limits for 5 shells from a greater depth (175-137 m), as well as 2 dates of the carbonate content of the $<63 \mu \mathrm{m}$ grainsize fraction of the bulk sediment ( 80 and $104 \mathrm{~m}$ depth). The shell dates show a smooth, consistent age profile. In contrast, the ages of the foraminifera show a jagged profile with age inversions and large discrepancies between mixed and monospecific samples. The observed age differences are of the order of several thousand years. 


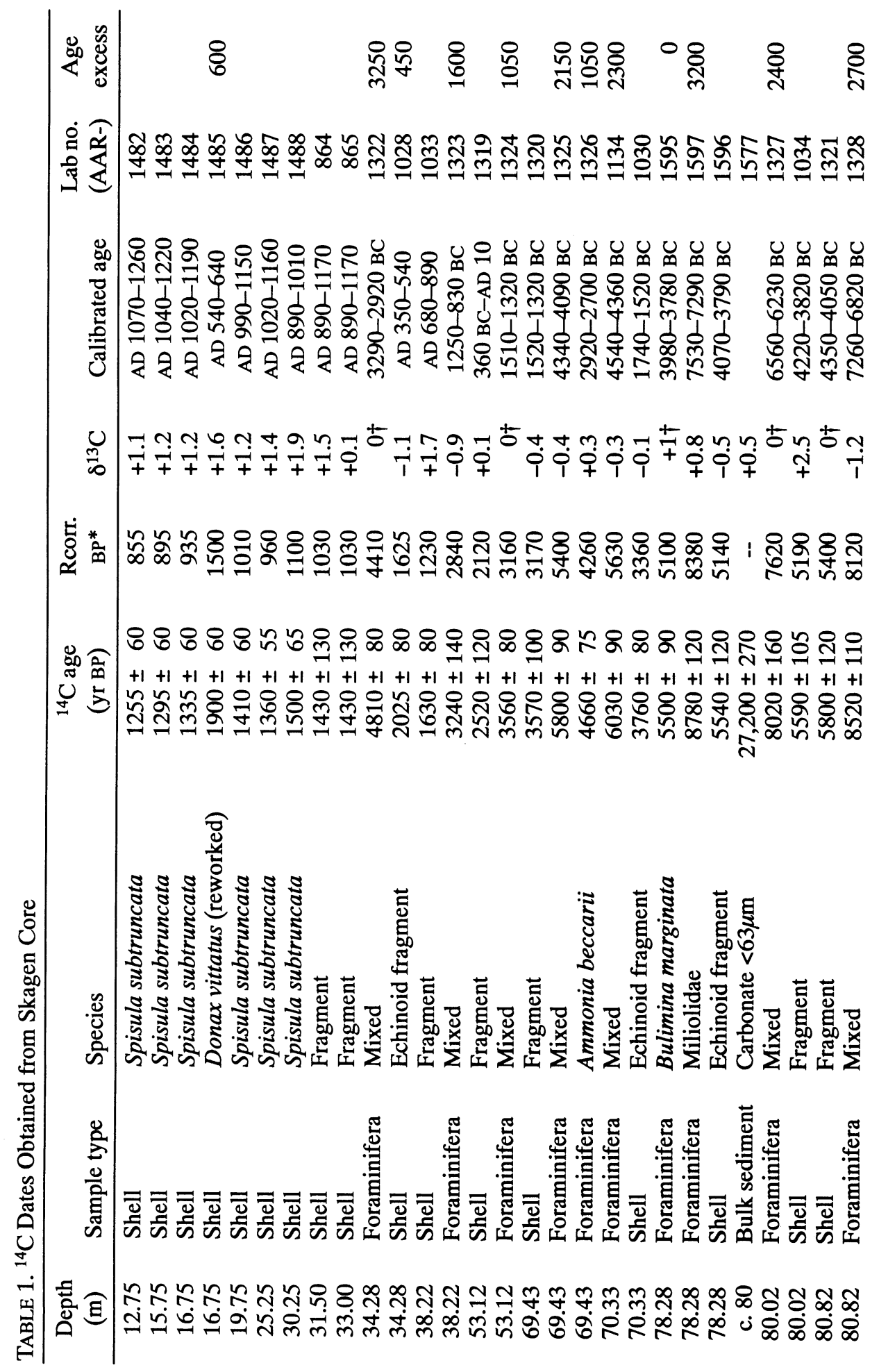




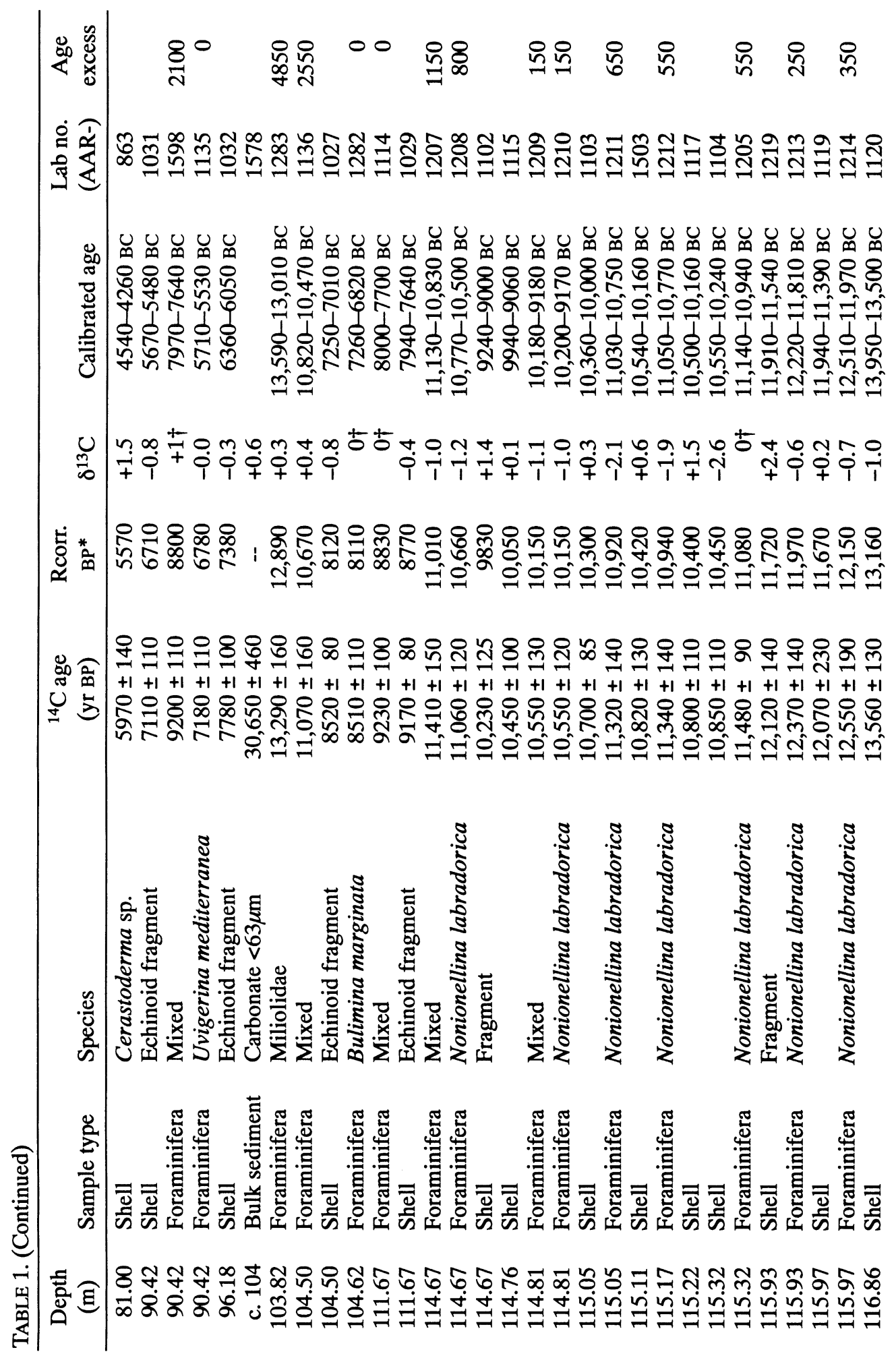




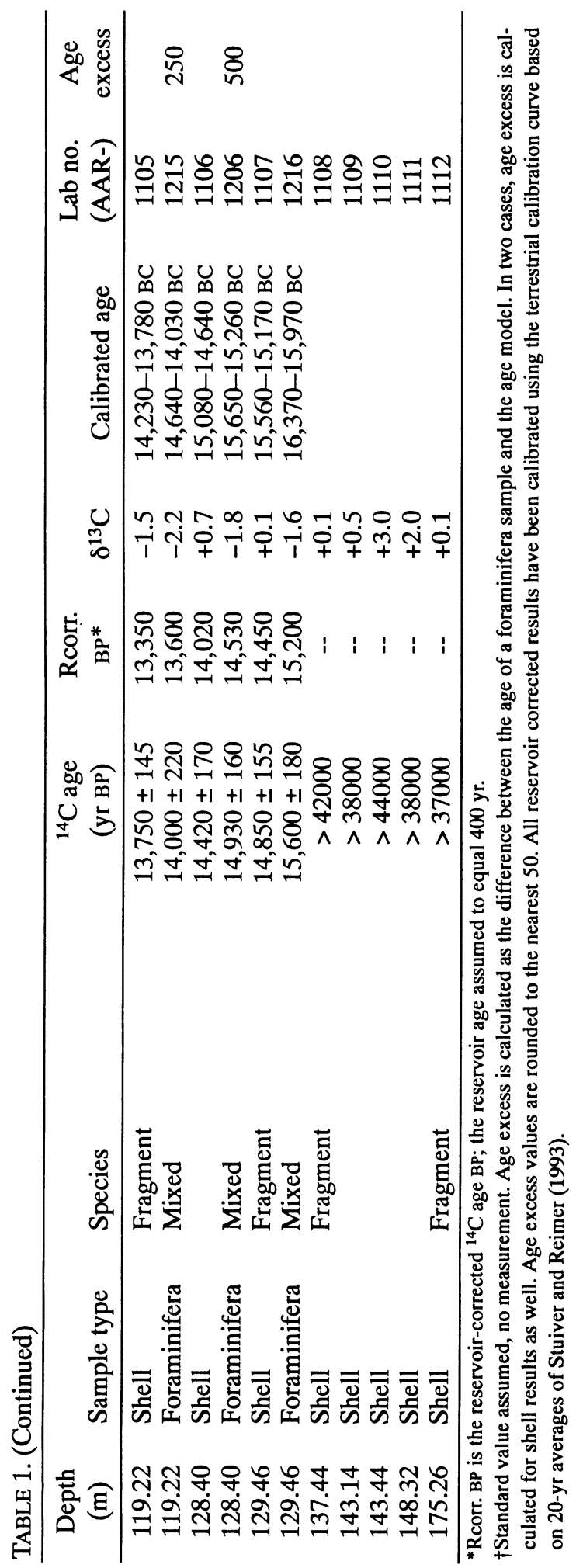




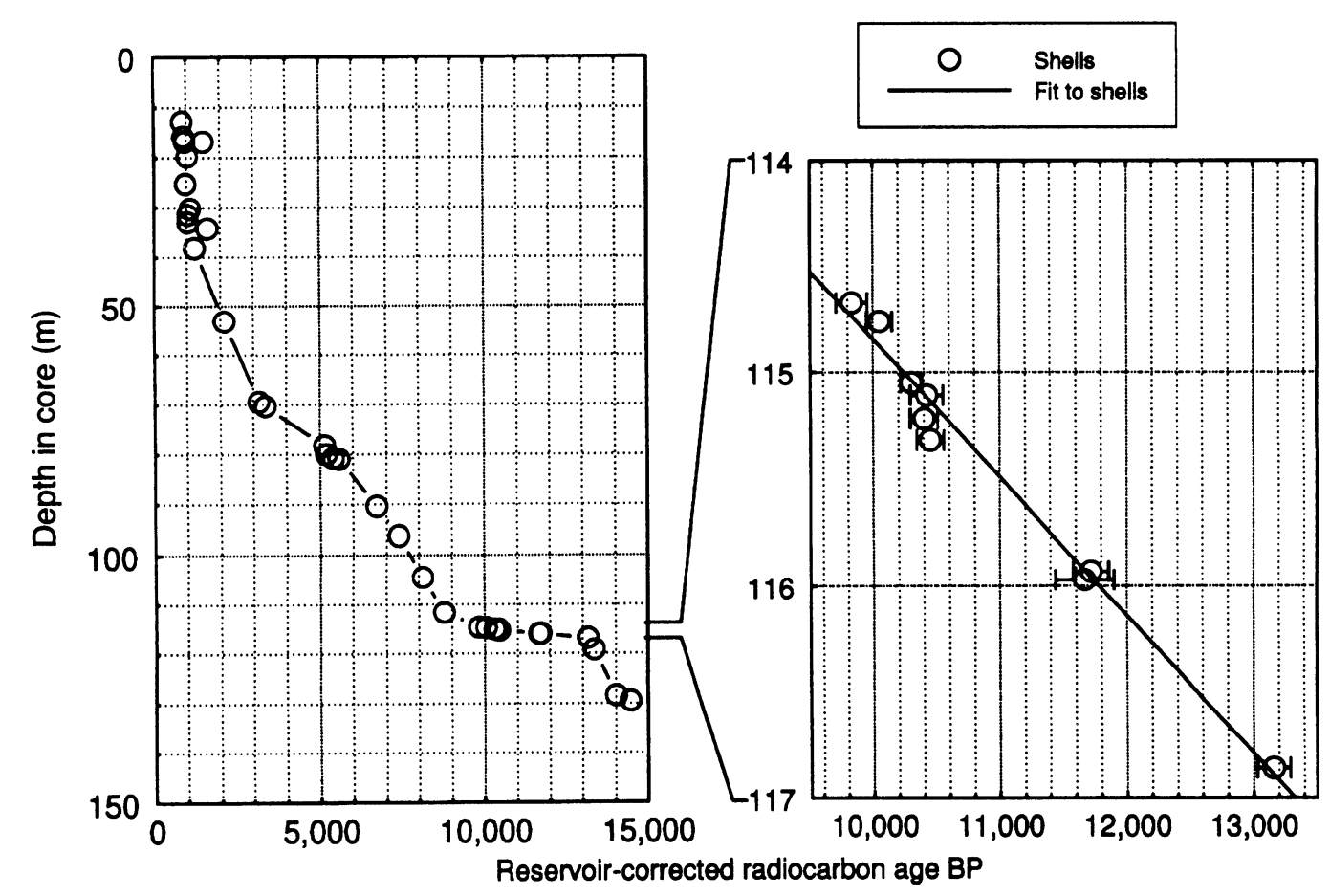

Fig. 2. Shell AMS dates of the Skagen Core. Results are given as conventional ${ }^{14} \mathrm{C}$ ages, corrected for a reservoir age of $400 \mathrm{yr}$. If experimental uncertainties are smaller than or equal to the point size, they are omitted.

We propose that the age profile of the shells represents the true age of the sediment, i.e., the time of its deposition. The smooth interpolated age curve for the shells is taken to represent a model of the sediment age. Only two shell dates fall outside this curve. Both shells were from the top, coarsegrained $30 \mathrm{~m}$ of the core where the sedimentation rate reaches the extremely high value of $70 \mathrm{~m} \mathrm{ka}^{-1}$, consistent with a high-energy coastal environment. One case is a specimen of Donax vittatus, found at $16.8-\mathrm{m}$ depth, which turned out to be $600 \mathrm{yr}$ older than the sediment age. This shell showed clear signs of mechanical reworking, and was dated only because of specific interest in the history of this species. The other case is from $34.3 \mathrm{~m}$ where a shell fragment is $450 \mathrm{yr}$ older than the interpolated age. At $34.3 \mathrm{~m}$, we also recorded the largest deviation, $2700 \mathrm{yr}$, for a mixed foraminiferal sample in the whole core. These age deviations can be explained only by reworking.

From the shell age profile, we deduce sedimentation rates ranging from $c a .1 \mathrm{~m} \mathrm{ka}^{-1}$ at $117-114 \mathrm{~m}$ (Late Glacial) with a steep increase to $14 \mathrm{~m} \mathrm{ka}^{-1}$ in the interval $114-38 \mathrm{~m}$, and up to $70 \mathrm{~m} \mathrm{ka}^{-1}$ for the coarse, sandy sediment of the top $30 \mathrm{~m}$ of the core where hardly any foraminifera are present. This increase in sedimentation rate is associated with a decrease in water depth from $c a .100-0 \mathrm{~m}$.

The data points for the foraminifera show an irregular pattern with large deviations from the sediment ages; yet some consistent features are important clues to the possible cause of the deviations. Several points are "normal" inasmuch as they agree closely with the age model; they are dates of monospecific samples of Bulimina marginata, Uvigerina mediterranea, Nonionellina labradorica and certain mixed samples occurring at core depths 78.3, 90.4, 104.5, 111.7, 114.8, 115.9 and 119.2 $\mathrm{m}$. Where points deviate from the age model, the age of the foraminifera is always higher than that of the corresponding shell, and this age excess can be quite large. The dates of the foraminifera fall 


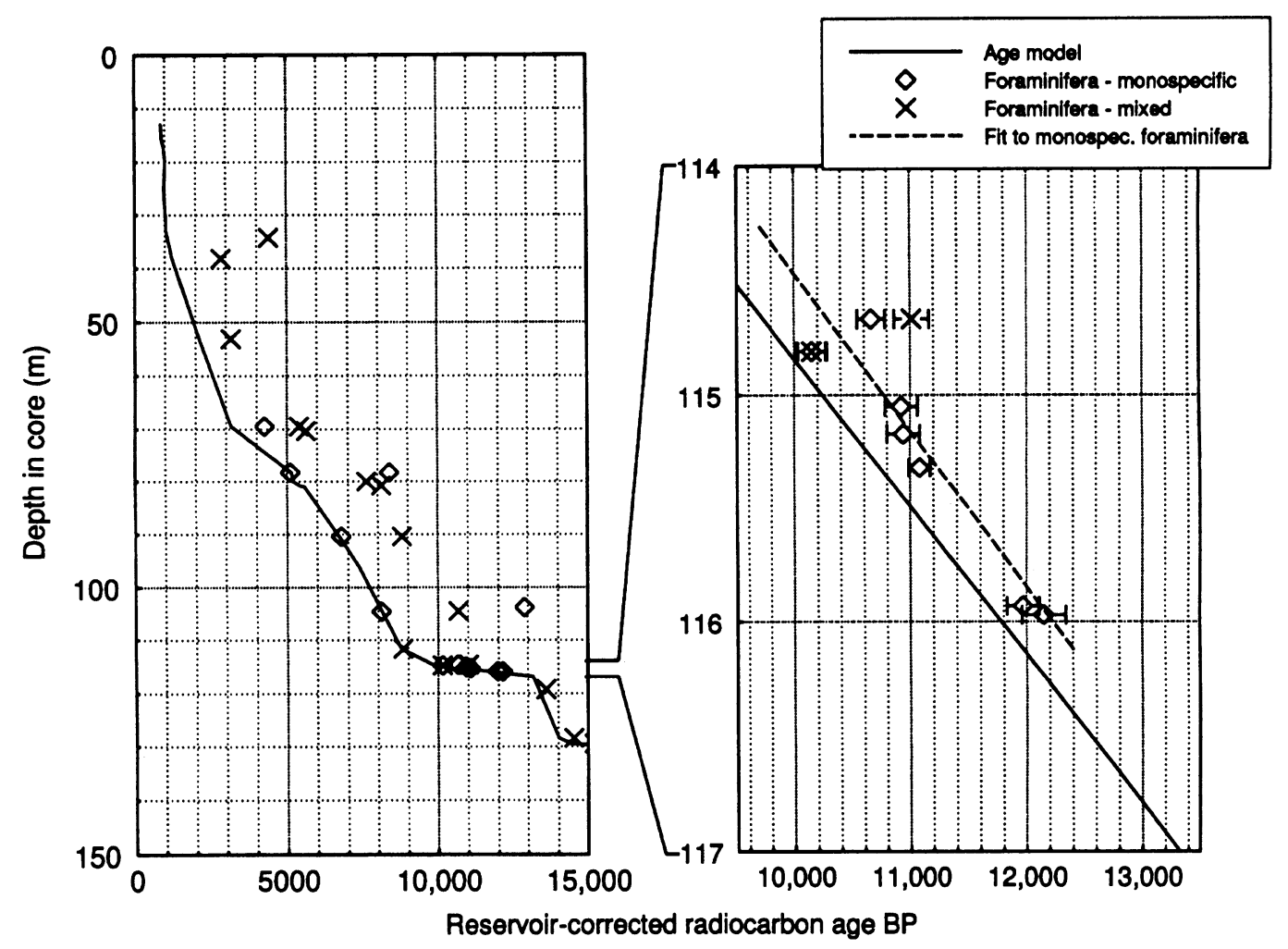

Fig. 3. Foraminiferal AMS dates of the Skagen Core. The macrofossil shell dates are indicated by the smooth curve. Results are given as conventional ${ }^{14} \mathrm{C}$ ages, corrected for a reservoir age of $400 \mathrm{yr}$. If experimental uncertainties are smaller than or equal to the point size, they are omitted.

in two distinct groups: they either agree exactly with the age model or they deviate substantially from it. There are four levels in the Holocene part of the core where the dates of foraminifera and shells agree closely. The calculated mean value of the differences, at these four levels, is $20 \pm 70 \mathrm{yr}$ (the uncertainty is the standard deviation of the mean computed from the statistical uncertainties in Table 1). The empirical standard deviation of the mean of the four differences is $30 \mathrm{yr}$. Where the dates of the foraminifera disagree, the difference is in the range of 1 to $5 \mathrm{ka}$.

An illustrative example occurs at $c a .104 .5 \mathrm{~m}$, where we measured a mixed-sample age excess of $2600 \mathrm{yr}$. We measured two other samples from about the same level, a monospecific sample of Bulimina marginata and one of large-sized Miliolidae. The age of the latter was as much as $4900 \mathrm{yr}$ older than the sediment age. Clearly, the miliolids must be responsible for a large part of the offset of the mixed sample. In contrast, the smaller-sized Bulimina marginata agreed exactly with the shell age within the experimental uncertainty of $100 \mathrm{yr}$.

The general pattern in the core, with a few exceptions, is that age excess increases with sedimentation rate. Between 117 and $114 \mathrm{~m}$ in the core (Late Glacial, Fig. 3) deposited at the lowest sedimentation rate and at water depths of the order of $100 \mathrm{~m}$, the deviations are relatively small and uniform, ca. $600 \mathrm{yr}$. Thus, a least-squares fit to the foraminiferal ages gives a line that is displaced $600 \mathrm{yr}$ toward the old side of the shell curve. During the Early Holocene (from $114 \mathrm{~m}$ upward, Fig. 3), with 
sharply increasing sedimentation rates at decreasing water depth, the deviations become larger and more erratic.

We cannot rule out $a$ priori the possibility that the observed age excesses of foraminifera are caused by contamination of the microfossils with old carbon either in situ or in the laboratory handling of the samples. We investigated the following three possible sources of systematic uncertainty:

1. Effect of carbonaceous sediment trapped inside foraminiferal shells. We estimated that inclusions of fine-grained carbonaceous sediments in the foraminiferal chambers cannot explain the large age excesses e.g., at levels 80 and $104 \mathrm{~m}$. At these levels, the carbonate content of the $<63 \mu \mathrm{m}$ grain size fraction was only $10 \%$ and dated to 27,200 and $30,500 \mathrm{BP}$, respectively. A significant apparent age increase due to contamination with dead carbonate from fine-grained sediment in the chambers would thus have revealed itself by a low $\mathrm{CO}_{2}$ yield from the foraminiferal samples. However, the measured carbonate content was typically $>80-90 \%$, corresponding to a maximum apparent age increase of 160-80 yr. If, e.g., the above-mentioned 4900-yr age excess for the large Miliolidae at $104.5 \mathrm{~m}$ were due to trapped sediment, the measured carbonate yield would have been $20 \%$ rather than the observed yield of $96 \%$.

2. Exchange of carbon between foraminifera and dissolved carbonate. If this process were significant, it would be impossible to explain the fact that totally unaffected foraminiferal species with dates in exact concordance with the shell age co-exist at several levels with species having large age deviations.

3. Contamination with carbon from $\mathrm{CCl}_{4}$ and/or tap water used in processing foraminiferal samples. Large samples, 2 near-modern and 1 background sample (Eemian) of foraminifera, handpicked without further processing, were divided into subsamples and subjected to different treatments. Figure 4 shows no significant effect of the treatment of $\mathrm{CCl}_{4}$ or tap water in the dating results.

We conclude that contamination, in situ or during handling in the laboratory, cannot be responsible for the observed age excesses.

All evidence points to reworking of foraminifera as the actual cause of the age discrepancies between shells and foraminifera in the present case. The effect of bioturbation and related effects (Andrée et al. 1984; Broecker et al. 1984; Peng and Broecker 1984) is negligible here due to the extremely high sedimentation rates of the Skagen Core. Part of the foraminiferal content in the sediment was deposited by lateral transport of older fossil material. As a quantitative example, we calculate that, at the $104-\mathrm{m}$ level, $c a .60 \%$ by weight of the foraminiferal sample (age excess $2600 \mathrm{yr}$ ) are reworked specimens, if we assume that all the reworked foraminifera have the same age excess (4900 yr, Late Glacial) as the dated large Miliolidae.

Sand-grain-sized foraminifera are comparable to much smaller, silt-sized quartz grains with respect to hydrodynamic transportation properties (e.g., Oehmig 1993). The reason is that foraminiferal shells, with thin, water-filled structures, have much lower effective density (grain bulk density minus density of water) than quartz particles. This makes entrainment and transport of foraminifera highly probable, especially in a high-energy environment.

The foraminiferal species show very different behavior in the present study. Thus, certain species (e.g., Bulimina marginata) are found almost exclusively in situ, buried in sediment mixed with reworked older foraminiferal shells belonging to a range of other species (e.g., Miliolidae). 


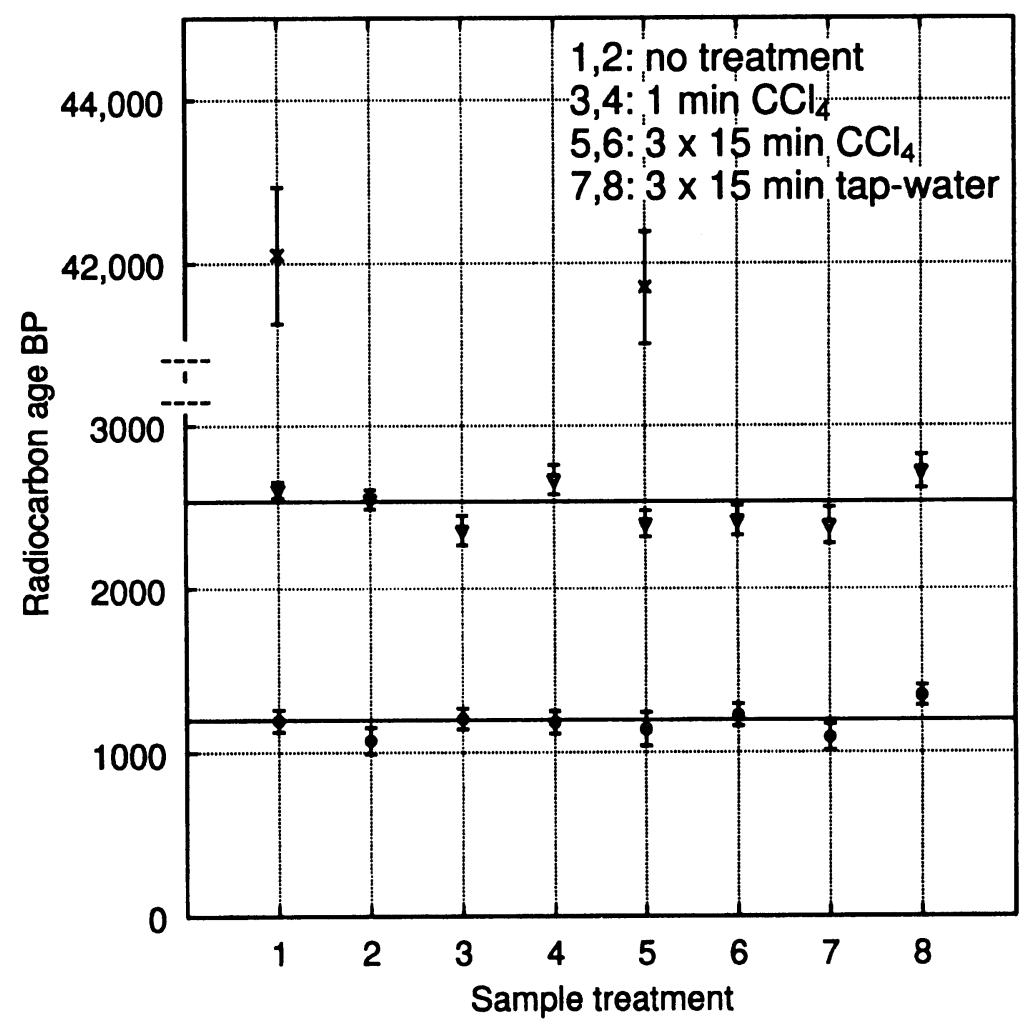

Fig. 4. Results of a test on possible carbon contamination from $\mathrm{CCl}_{4}$ and tap-water treatments in the processing of foraminiferal samples. Three large samples of handpicked foraminifera were divided into subsamples and subjected to different treatments. Subsamples 1 and 2 act as reference samples. Subsamples 3 and 4 were given the normal $\mathrm{CCl}_{4}$ treatment, whereas 5 and 6 were subjected to a prolonged treatment. Subsamples 7 and 8 were washed with hot tap water for $3 \times 15$ min and dried under infrared light after each treatment. $\times$ is a background sample, ca. $42,000 \mathrm{BP} ; \boldsymbol{\nabla}$ and $\bullet$ are samples with average ages of $2500 \mathrm{BP}$ and $1200 \mathrm{BP}$, respectively.

Is there a "best choice" of foraminiferal species for dating a sediment? Can we select in-situ species? The Skagen Core provides an example of a possible answer: We found that the species Bulimina marginata (at $78.3 \mathrm{~m}$ ) and Uvigerina mediterranea (at $90.4 \mathrm{~m}$ ) agreed precisely with the corresponding shell dates. These species are clearly in situ and are not seen as reworked fossils in the core. Thus, they are perfect dating tools for this core. This was predictable because these species are rare in the southerly source regions of the northbound Jutland Current that transported the sediments. Thus, the paleoenvironmental interpretations enabled us to select in-situ species.

Concordance between two species as well as a smooth age profile have been proposed as criteria for the reliability of foraminiferal dating in deep-sea cores (Broecker et al. 1989). We emphasize that, in the present study, these criteria are not sufficient to exclude that foraminiferal samples are influenced by reworking. For example, in dating foraminifera of a Late Glacial part of the Skagen Core, we observed concordance between monospecific and mixed samples (at 114.6 and $114.8 \mathrm{~m}$, see Fig. 3) and a smooth age profile. If we had relied on this, we would have introduced an undetected age bias of $600 \mathrm{yr}$ in the dating of the core. 


\section{CONCLUSION}

We conclude that foraminiferal shells are well suited for ${ }^{14} \mathrm{C}$ dating because the measured age marks the true time of death of the organism. However, dating sediments via foraminifera may cause problems because the microfossil shells are likely to be affected by reworking, as demonstrated here. In the present shelf core, the reworked foraminifera are recognized easily from their large age excesses, in particular when the sedimentation rate is high, as in the Holocene part of the core. In a deep-sea core, reworking of foraminifera might be less frequent than in a shelf core, but may also be less easily detected due to lower resolution and the smoothing effect of bioturbation.

We plan to extend the present study of shelf sediments to cores, both from the continental slope and the deep sea, to compare the effects of reworking processes in these different environmental regimes.

\section{ACKNOWLEDGments}

We gratefully acknowledge financial support from the Danish Natural Science Research Council. We thank Peter Kristensen for his contribution in sampling as well as valuable discussions. Kaj Strand Petersen of the Geological Survey of Denmark carefully selected the shell samples for ${ }^{14} \mathrm{C}$ dating from the upper $30 \mathrm{~m}$ of the core.

\section{REFERENCES}

Andersen, B. G. 1968 Glacial geology of Western Troms, North Norway. Norges Geologiske Undersøkelse 256: $1-160$.

Andersen, G. J., Heinemeier, J., Nielsen, H. L., Rud, N., Thomsen, M. S., Johnsen, S., Sveinbjörnsdóttir, Á. and Hjartarson, A. 1989 AMS ${ }^{14} \mathrm{C}$ dating on the Fossvogur sediments, Iceland. In Long, A., Kra, R. S. and Srdoc, D., eds., Proceedings of the 13th International ${ }^{14} \mathrm{C}$ Conference. Radiocarbon 31(3): 592-600.

Andrée, M., Beer, J., Oeschger, H., Broecker, W., Mix, A., Ragano, N., O’Hara, P., Bonani, G., Hofmann, H. J., Morenzoni, E., Nessi, M., Suter, M. and Wölfli, W. $1984{ }^{14} \mathrm{C}$ measurements on foraminifera of deep sea core V28-238 and their preliminary interpretation. Nuclear Instruments and Methods in Physics Research B5: 340-345.

Bard, E., Fairbanks, R., Arnold, M., Maurice, P., Duprat, J., Moyes J. and Duplessy, J.-C. 1989 Sea-level estimates during the last deglaciation based on $\delta^{18} \mathrm{O}$ and accelerator mass spectrometry ${ }^{14} \mathrm{C}$ ages measured in Globigerina bulloides. Quaternary Research 31: 381391.

Broecker, W. S., Andrée, M., Bonani, G., Wölfli, W., Klas, M., Mix, A. and Oeschger, H. 1988 Comparison between radiocarbon ages obtained on coexisting planktonic foraminifera. Paleoceanography 3(6): $647-658$.

Broecker, W. S., Mix, A., Andrée M. and Oeschger, H. 1984 Radiocarbon measurements on coexisting benthic and planktic foraminifera shells: Potential for reconstructing ocean ventilation times over the past 20,000 years. Nuclear Instruments and Methods in Physics Research B5: 331-339.
Broecker, W. S., Trumbore, S., Bonani, G., Wölfli, W. and Klas, M. 1989 Anomalous AMS radiocarbon ages for foraminifera from high-deposition-rate ocean sediments. Radiocarbon 31(2): 157-162.

Conradsen, K. and Heier-Nielsen, S. 1995 Holocene paleoceanography and paleoenvironments of the Skagerrak-Kattegat, Scandinavia. Paleoceanography 10 (4): 801-813.

Fairbanks, R. G. 1989 A 17,000-year glacio-eustatic sea level record: Influence of glacial melting rates on the Younger Dryas event and deep-ocean circulation. $\mathrm{Na}$ ture 342: 637-642.

Feyling-Hanssen, R. W., Jørgensen, J. A., Knudsen, K. L. and Lykke-Andersen, A.-L. 1971 Late Quaternary foraminifera from Vendsyssel, Denmark and Sandnes, Norway. Bulletin of the Geological Society of Denmark 21: 67-317.

Jones, G. A., Jull, A. J. T., Linick, T. W. and Donahue, D. J. 1989 Radiocarbon dating of deep-sea sediments: A comparison of accelerator mass spectrometer and beta-decay methods. Radiocarbon 31(2): 105-116.

Knudsen, K. L. 1994 The marine Quaternary in Denmark: A review of new evidence from glacial-interglacial studies. Bulletin of the Geological Society of Denmark 41: 203-218.

Kristensen, P., Heier-Nielsen, S. and Hylleberg, J. 1995 Late-Holocene salinity fluctuations in Bjoernsholm Bay, Limfjorden, Denmark, as deduced from microand macrofossil analysis. The Holocene 5(3): 313-322.

Krog, H., Tauber, H. 1974 C-14 chronology of late- and postglacial marine deposits in North Jutland. Geological Survey of Denmark, Yearbook 1973: 93-105.

Nielsen, S. H. 1992 Foraminiferanalyse, ${ }^{14} \mathrm{C}$-dateringer 
og stabil isotop analyse i kerne 95, Limfjorden. Dansk geoklogisk Forening, Arsskrift for 1990-1991: 39-45.

Nielsen, S. H., Heinemeier, J. and Rud, N. 1994 High marine reservoir ages for Danish fiords compared to open waters. (Abstract) 15 th International ${ }^{14} \mathrm{C}$ Conference, Glasgow, Scotland, 15-19 August.

Oehmig, R. 1993 Entrainment of planktonic foraminifera: Effect of bulk density. Sedimentology 40: 869877.

Olsson, I. and Blake, W. 1961 Problems of radiocarbon dating of raised beaches, based on experience in Spitsbergen. Norsk Geografisk Tidsskrift 18: 47-64.

Peng, T.-H. and Broecker, W. 1984 The impacts of bioturbation on the age difference between benthic and planktonic foraminifera in deep sea sediments. $\mathrm{Nu}$ clear Instruments and Methods in Physics Research
B5: $346-352$

Seidenkrantz, M.-S. and Knudsen, K. L. 1993 Middle Weichselian to Holocene palaeoecology in the eastern Kattegat, Scandinavia: Foraminifera, stable isotopes and ${ }^{14} \mathrm{C}$ measurements. Boreas 22: 299-310.

Stuiver, M. and Polach, H. A. 1977 Discussion: Reporting of ${ }^{14} \mathrm{C}$ data. Radiocarbon 19(3): 355-363.

Stuiver, M. and Reimer, P. J. 1993 Extended ${ }^{14} \mathrm{C}$ data base and revised CALIB $3.0{ }^{14} \mathrm{C}$ age calibration program. In Stuiver, M., Long, A. and Kra, R. S., eds., Calibration 1993. Radiocarbon 35(1): 215-230.

Vogel, J. S., Southon, J. R., Nelson, D. E. and Brown, T. A. 1984 Performance of catalytically condensed carbon for use in accelerator mass spectrometry. Nuclear Instruments and Methods in Physics Research B5: 289-293. 